\title{
Assassinato no expresso do Oriente
}

\author{
Eloah Pina Pereira
}

Resumo: Tradução de conto da coletânea ЖА-Рассказы (Contos de ferrovia), de Dmitri Lvóvitch Býkov.

Palavras-chave: Literatura russa contemporânea; Dmítri Býkov; intertextualidade; histórias de trem; tradução

\section{Nota biográfica}

Dmítri Lvóvitch Býkov nasceu em Moscou, em 1967. Jornalista de formação, é editor, professor, palestrante, radialista e um dos mais prolíferos - e polêmicos - escritores russos contemporâneos. Inédita em português, a coletânea de contos ЖА-Рассказы (Contos de ferrovia) foi publicada em 2007 após seus contos terem sido encomendados para a revista da companhia estatal de trens, Саквояж CB (Valise SV, sigla em russo para vagão-leito), sob a temática das histórias de trem. Nela, Býkov destila toda sua ironia e humor, fazendo uso constante da coloquialidade e do intertexto, seja esse relacionado ao passado soviético ou à cultura pop que passou a invadir a vida russa a partir dos anos 1990. Assassinato no expresso do Oriente, homônimo do romance de Agatha Christie, é um exemplo de como Dmítri Býkov faz uso do cronótopo da via férrea, recorrente na literatura russa, deixando clara sua irreverência iconoclasta em vários momentos da narrativa.

\section{Assassinato no expresso do Oriente (Dmítri Lvóvitch Býkov)}

Primeiro serviram gelatina de alce, depois taimen rosa defumado que derretia na boca, patê lilás picante feito de caça, queijo Okhótnitchi com cheiro-verde, em seguida carne de urso marrom-avermelhada, seca e fibrosa, um prato de pinhões descascados, com tudo isso, a vodca Taiga no gengibre, depois um caldo forte com 
pelmenis artesanais redondos e gordos - de novo, feitos de alce -, depois costelas de javali assadas com repolho, alho selvagem salgado e brusnica em conserva, e Volódia Coqtelho-Perverte ${ }^{1}$ devorou tudo. Devorou, mexendo os maxilares vigorosamente, aprovando com a cabeça para as garçonetes, piscando para o tradutor, devorou, como se não tivesse sido alimentado na França, na Alemanha e na Polônia, onde estivera antes da turnê russa, como se estivesse se empanturrando para vingar toda sua juventude faminta, gasta na compreensão da suprema sabedoria em mansardas de Paris e favelas de Buenos Aires. Um escritor europeu petiscaria com requinte ali, cheiraria aqui e pegaria um pedacinho de pão - seria suficiente; mas Coqtelho-Perverte era latino-americano e bem sabia que, enquanto oferecerem comida, é preciso devorar. Depois não haverá mais. Apenas essa grande escola da vida vivida impetuosamente reconciliou Syromiátnikov ${ }^{2}$ com Perverte, ainda que em parte. Sentia-se que era um homem que não só cheirava, mas que sorvia o pão todo.

Célebre autor de romances policiais esotéricos, conquistador do mercado literário internacional, amigo pessoal da Madonna, parceiro preferido do Paul McCartney no bridge, no críquete e na meditação transcendental, confidente do Maradona, talismã da seleção argentina de hóquei na grama, convidado habitual da Sorbonne, padrinho do filho ilegítimo de Celentano ${ }^{3}$ e afilhado do dalai-lama, batizado no budismo com o nome de Sutipon Brrátrrábratrrá, que significa, só pode ser, verme cabeçudo careca que pretende parecer um líder espiritual - Volódia Coqtelho-Perverte nasceu em uma família de um grande latifundista, isto é, proprietário de terras, no ano de 1951. O pai se afeiçoara aos ideais de Lênin e homenageou-o dando seu nome ao filho, mas, para a felicidade de Volódia, ele se contentava com a teoria, praticando o capitalismo predatório da maneira mais mafiosa possível. O filhinho, professor espiritual dos estudantes europeus, ídolo dos campi norte-americanos e dos companheiros cubanos, herdou do papai a feliz capacidade de professar uma coisa e praticar outra. Foi estudar em Paris, lá provou todo tipo de neuroestimulantes e psicodélicos, largou os estudos, foi clochard debaixo de pontes, viajou pela Europa, ganhou a vida de todo jeito - de kidnapping até cunilíngua - e foi descoberto pelo papai preocupado em uma comunidade maoísta-rastafári de Amsterdã que venerava uma negra grávida, Mãe dos Mundos.

1 O sobrenome Coqtelho-Perverte é um trocadilho com os sobrenomes de escritores contemporâneos Paulo Coelho e Arturo Pérez-Reverte.

2 O sobrenome Syromiátnikov vem da palavra Syromiátnik, que em russo significa curtidor, aquele que faz curtumes.

3 Adriano Celentano, cantor, compositor e ator italiano nascido em 1938. Muito popular na União Soviética por ser protagonista das comédias Um blefe de mestre (1976), Loucamente apaixonado (1981) e Bingo Bongo (1982). 
O papai concluiu, com razão, que a formação do filho estava concluída, e o pôs para descansar em um hospital psiquiátrico em Buenos Aires, onde Volódia pela primeira vez foi transpassado pela chamada Luz Cor de rosa. Sob a ação dessas ondas mornas, ele psicografou, como se fosse ditado das alturas, as primeiras páginas do romance policial esotérico $A$ morte do beduíno, cujo herói, o detetive e místico Raban, viajando por épocas e continentes, no fim das contas desmascarou o mal mundial. Perverte estava sem absolutamente nada para fazer na clausura confortável, as pílulas eram dosadas corretamente (sim, dizem, aliás, ter seduzido uma bela enfermeira que também o abastecia com haxixe) - apenas lia e alucinava. Ele leu As mile uma noites, Borges, os sufistas, um par de interpretações populares do Novo Testamento e criou um gênero que lhe trouxe grande fama. Todos os vinte e três romances policiais místicos malfeitos sobre viagens do Raban por Borges e pelos sufistas, com paradas regulares no Vaticano, em Meca, Jerusalém, na época das cruzadas e do florescimento de Veneza, pareciam iguais a uma goma árabe embrulhada numa página da Enciclopédia Britânica puída. Certa vez, Syromiátnikov comprou essa goma árabe em Istambul e surpreendeu-se com a semelhança literal: viscosa, doce, e a todo esse grude exótico se prendiam fragmentos de manual de história. No entanto, os intelectuais sabichões elegeram Perverte o principal latino-americano pós-modernista, enquanto o leitor comum comprou $A$ morte do mufti, $O$ corão roubado e Cabala dos hipócritas em tamanha quantidade que depois de cinco anos de carreira literária Volódia adquiriu o hospital psiquiátrico onde teve a iluminação e ali fundou a Escola Interconfessional de Iluminação Espiritual. Lá se estudava seu testamento espiritual para os povos do mundo todo - Livro de cabeceira do Cavaleiro Iluminado. A contadora era aquela negra sempre grávida que ele venerara em Amsterdã.

Coube a Syromiátnikov traduzir tudo isso - na universidade ele aprendeu espanhol. Ele também escrevia romances policiais, e bem melhores que os de Coqtelho, mas não tinham serventia para ninguém, já que os heróis de Syromiátnikov eram mortos não no Louvre, mas em um hotel provinciano, e os assassinos não eram monges da sociedade secreta voltairiana, mas desempregados locais levados ao desespero. De seus romances policiais não dava para arrancar sequer uma novelinha. Consequentemente, ele mamava nas tetas de Coqtelho e já arrastara para a língua materna dos choupos-tremedores ${ }^{4}$ seis de seus cacarecos típicos,

4 Citação de um dos versos do epigrama escrito por Turguêniev para Nikolai Khristofórovitch Kettcher, jornalista e tradutor, que traduzira Shakespeare para o russo, em prosa. A tradução foi malvista pelos contemporâneos e, mais tarde, a expressão tornou-se popular para fazer referência às más traduções. "Eis que o mundo ainda era claro/ Kettcher, amigo dos vinhos espumantes/ Estragduziu Shakespeare para nós/ na língua materna dos choupos-tremedores." 
incluindo o recém-lançado Código de Afrodite. A moda russa de Vladímir começou com Makarévitch, ${ }^{5}$ que conheceu o gordo bronzeado quando foi mergulhar nos mares do sul e o convidou para ir à Rússia. Ele também trouxe para cá um exemplar da Agenda do guerreiro de prata e, durante as apresentações de mais um disco, mostrou-o para o editor-chefe do Eksnia. ${ }^{6} \mathrm{O}$ Eksnia rapidamente percebeu o que farejara - lhe ofereciam toda a cultura e religião mundial em um só frasco, mastigada, vomitada e apimentada -, e logo a enorme bocarra do guerreiro da luz escancarou-se em todos os billboards. A divulgação foi audaciosa e, no auge da moda, Coqtelho foi convidado ao Oriente nevado do espírito mundial, como chamou a Rússia já na primeira entrevista moscovita. O título do novo romance tornou-se slogan da viagem: Rumo ao Oriente! Perverte expressou o desejo de atravessar a Rússia - de Moscou até Tchitá -, encontrando-se com os admiradores em cidades grandes e abençoando de longe as pequenas. No expresso do Oriente Baikal Azul engancharam um salão-vagão, e nele equiparam uma cabine de luxo para Perverte, uma para a secretária sérvia viril, e ainda uma para o secretário colombiano afeminado (Syromiátnikov ainda não entendera com qual deles o guerreiro da luz tinha um caso), para o próprio tradutor designaram um cubículo modesto perto do banheiro, e diante dos flashes o amigo da Madonna se lançou à sua primeira peregrinação russa.

Ele era, na maioria das vezes, um cara bom, que sabia perfeitamente o preço de seus produtos. Vestindo-se com uma bata prateada bordada e um turbante branco-neve, antes da parada em Kazan e Novossibirsk, Coqtelho assobiou baixinho algo revolucionário, e com um olhar tão trapaceiro que, dessa vez, Syromiátnikov não conseguiu resistir e piscou para ele. Traduzir sua algaravia era surpreendentemente fácil - ele falava completos absurdos e deixava que o tradutor o adornasse como quisesse. "Eu não me ofendo, amigo", 7 disse retumbante durante o primeiro encontro, "se na tradução simultânea você se afastar do original o quanto quiser. Confie na sua imaginação, que foi induzida pela presença do meu espírito poderoso! Há! Há!" - e Syromiátnikov não se recusava a nada. "Jejum regular nos dias pares, abstenções de deveres conjugais nos ímpares, contemplação da constelação Rato Pensativo, como nós no Brasil chamamos a Ursa Maior, e limpeza dos chacras por escovas de limpeza higienizantes da marca Salem, da qual eu sou sócio, ajuda você já no final do primeiro ano das aulas a alcançar o Grau de

5 Andrei Vadímovitch Makarevitch, músico e rock star moscovita nascido em 1953.

6 Referência а Эксмо [Eksmo], uma editora moscovita de grande porte que publica também os livros de Arturo Pérez-Reverte em russo.

7 Em espanhol no original. 
Absorção, do qual apenas um passo e meio ano de treino o separam do Estágio de Defecação!" - descaradamente tagarelava ele, quase sem ouvir os balbucios de Vladímir. À noite eles bebiam admiravelmente no salão do mestre, graças ao editor, que não economizou com seu amado Jack Daniels.

- Meu poder de adivinhação está me dizendo, jovem amigo - disse Perverte com malícia, apertando os olhos -, que você mesmo escreve de vez em quando, ah sim, e muito bem. Admita, adivinhei?

- Não posso negar.

- E já publicou?

- Um pouco.

- Não tem problema, todos começam com alguma coisa... Parece-me que todo seu problema está no fato, companiero, de que você não conhece a vida. Fidel também, quando caçávamos nas suas propriedades, certa vez me disse: a vida, é preciso conhecer a vida! Che lia livros, enquanto eu conhecia a natureza humana - e agora, onde eu estou e onde está Che? Assim me disse Fidel, e Fidel é um rapaz astuto. Eu viajei, ah sim, eu vi de tudo - e ele inventava mais uma história que Maksim Górki invejaria. Perverte atravessou toda a Europa, viveu um mês entre pigmeus africanos, filmou um documentário sobre pinguins reis, fez caridade entre os aborígines da Oceania, em toda parte degustava a culinária nacional e deixava descendentes. - Eu me espalhei generosamente nesse mundo sujo, é isso, amigo! ${ }^{8}$ É preciso viver com gosto, como me disse Hugo Chávez, quando tirou todos os bens de mais um oligarca. Eis que você está com trinta e cinco anos, e do que você pode lembrar?

Syromiátnikov, é claro, tinha do que se lembrar - as estradas sujas das províncias russas, centenas de destinos despedaçados e milhares de expressões ácidas, para as quais ele olhava como redator do departamento de investigações do jornal Tribuna, pastas cinza dos mesmos processos penais - banditismo de um copeque e muitos anos de prisão, fugas sem sentido e mais anos de prisão, furto de fios e transformadores, afrouxamento dos trilhos, fugas do exército - mas com isso era impossível preparar um best-seller até do tipo de $O$ testamento do mouro. Por alguma razão, os leitores teimam em não querer ler sobre aquilo que os cerca, não estão nem aí para o sofrimento do vizinho paralisado e da vizinha empobrecida, mas choram rios de lágrimas pela Isaura, que vivia na outra ponta do mundo, e mesmo assim só na imaginação doentia do produtor.

8 Em espanhol, no original. 
Coqtelho estudou ampla e profundamente a vida russa. Nos encontros em livrarias, ele não falava tanto quanto ouvia; Syromiátnikov lhe traduzia crônicas criminais da imprensa local; ele não só beliscava as condutoras e garçonetes até ficarem roxas, para a felicidade delas, como também perguntava os mínimos detalhes biográficos, desde o início da menstruação até os hábitos da sogra; o apetite dele por comida, por bebida e por impressões era surpreendente. Às cinco da manhã, ele digitava em uma pequena Toshiba com um monograma pessoal, depois gravava no ditafone colunas para dois jornais argentinos (a transcrição ficava para o secretário), depois fazia correções na recém-concluída autobiografia para a Penguin Books (nisso a secretária ajudava), então almoçava com o mesmo empenho e dava uma vigorosa coletiva de imprensa em mais uma cidade siberiana. Syromiátnikov admirou-se com sua infatigabilidade e com a imensidão russa: Perverte produzira uma quantidade assustadora dos mesmos produtos e pela janela se arrastava a quantidade assustadora da mesma Rússia - em comparação com o ocidente compacto, o oriente russo surpreendia com sua redundância e negligência - e se pensarmos assim, hóspede e anfitrião foram feitos um para o outro. Em cada estação os admiradores davam suvenires a Perverte, ele dava mil autógrafos, não se cansava de perguntar o nome dos leitores e a cada cinco livros desenhava uma pomba, e à noite, quando pela janela se arrastava a longa, conífera, úmida escuridão, sem uma luzinha sequer - contava a Syromiátnikov os capítulos da futura autobiografia. Às vezes Syromiátnikov enjoava de Coqtelho, mas, de modo geral, ele era grato pelo sustento.

Em outros vagões - não tão luxuosos, mas também de elite - viajavam autoridades locais, funcionários públicos, business men, que não tinham nenhuma relação com a literatura, mas sabiam, é claro, que ao trem estava engatado o salão de um clássico vivo. Alguns, com autorização especial, entravam para conhecê-lo. No salão, visitaram Coqtelho o vice-governador de Tcheliábinsk, um grande financista de Ekaterinburgo, o chefe da empresa Safe Siberia, que fabricava contraceptivos, e o célebre ex-deputado federal da facção Indissolubilidade, agora banqueiro bem-sucedido do Extremo Oriente, Boris Kháilov - urso obeso, perto do qual Perverte parecia quase gracioso. Kháilov citava demoradamente a Agenda do Guerreiro de Prata, contava sobre seu caminho espiritual e sobre como ele doava muito para templos, e também sobre como a Rússia estava melhorando rápido sob a centralização do poder. Kháilov verificou que não tinha os livros de Coqtelho, e lhe ofereceu a barriga lisa de uma moça da agência de modelos Luzes Siberianas para autografar. Coqtelho pediu para a secretária virar-se e autografou a bunda da moça, arrancando dela a promessa de não lavar a bunda por pelo menos uma semana. 
- Interessante esse homem - disse ele à noite com um copo de Jack. Aprenda, amigo, enquanto ele está vivo. Algo me diz que ele não vai durar muito.

- Esses aí não morrem - resmungou Syromiátnikov.

- De morte natural quase nunca - acenou Coqtelho. - Um tipo admirável. Escuridão limpa, pura, sem nenhum vislumbre. Acho que o Senhor gostaria de pôr uma alma nele, mas não conseguiu encontrar sequer uma bolha de ar nesse monólito. Um fenômeno, um fenômeno. Vou reservá-lo para um romance.

- Entre nós, um em cada dois é assim - queixou-se da pátria Syromiátnikov.

- O senhor se engana. Antes do encontro, estudei a biografia dele, pedi a Rosa que preparasse um resumo para mim. - Chamava Rosa a uma sérvia que mais parecia um cedro libanês. - É admirável, não há lugar onde não tenha deixado pegadas. Vocês têm frequentemente uma só figura pública que roda por diversas áreas? Nós, na Argentina, no Brasil, não temos esse costume. Não acreditamos no management ocidental. Somente aqueles que passaram por todas as etapas e estudaram business minuciosamente podem ser chefes. E não houve o que esse não fosse - comissário militar, agente de compras, editor-chefe... Não, esse é um tipo muito interessante. Eu não gostaria de estar na pele dele nem por todos os aromas da Arábia. Aliás, contei a você como um xeque saudita me presenteou com uma concubina árabe albina?

Ele contou durante muito tempo, prazerosamente, com detalhes admiráveis - e só liberou Syromiátnikov às três horas da manhã, e apenas porque ele alegou uma leve diarreia. “Bom, você sabe, comida pesada....”. De manhã, Syromiátnikov escutou, em meio ao sono, como Perverte caminhava - com passos pesados pelo corredor ao banheiro e, depois de uma longa permanência lá, voltava - xingando de modo tão artístico que seria difícil para ele traduzir essa requintada obscenidade espanhola.

De manhã, próximo a Tchitá, no pequeno Krasnokámensk, onde Perverte não planejara nem encontro, nem sessão de autógrafos - o trem ficou parado por muito tempo. Todos eram proibidos de descer à plataforma. A estação estava lotada de policiais. Nela se agitavam em vão personagens de tipo burocrático, em paletós escancarados, com as carrancas desnorteadas e bravas. Enfim, tiraram do sétimo vagão algo enorme, coberto com um lençol branco, em uma maca.

- Desço para averiguar? - ofereceu-se Syromiátnikov.

- O que o senhor não entendeu? - perguntou Coqtelho altivo. - Esse é o nosso amigo, representante do partido Grudar-se, dono do banco Trakh-bakh, ou eu não avisei? 
- E o senhor adivinha o futuro? - perguntou Syromiátnikov acidamente. A presunção desse preferido de Rabindranath Tagore ${ }^{9}$ começou a cansá-lo.

- Como não. Ainda há cinco anos falei pro Paul: Paul, você vai largar a Heather, essa menina não é pra você. No começo ele riu, depois ficou com raiva. Faz um mês me mandou um bolo. Se ele me conhecesse na década de 80, talvez eu avisasse John também...

- E por que o senhor não salvou esse daí?

- Ora, pois ele já sabia - disse Coqtelho. - Só não sabia quando.

O trem se moveu somente perto do meio-dia. Coqtelho mastigava ómul, entregando-se a beber sua cerveja Porfírica Siberiana com ar sonhador.

- Então você é um escritor policial, ou pelo menos assim se declara - resmungou Syromiátnikov. - Estou certo, porém, de que caso tivesse que desvendar um assassinato de verdade, o senhor desistiria no mesmo instante.

- Na verdade, jovem - Coqtelho respondeu em tom moralizante, sem desviar o olhar da taiga através da janela -, o cozinheiro não vai à caça, e o metalúrgico não procura minério. Eu lavro a vida, mas não a refaço.

Essa grandiloquência oriental era-lhe especialmente repugnante - Syromiátnikov nunca entendeu como pessoas com ensino médio poderiam comprar tal aparência falsa e barata.

- Mas já que eu andei no meio dos outros e vi muito de tudo na juventude turbulenta - continuou Perverte, fumando um Uppman grosso - faria facilmente em pedacinhos um caso de dificuldade média, se não me atrapalhassem. Agora no sétimo vagão o inquérito está em andamento, a brigada inteira da polícia local foi enviada ao trem para esclarecer as circunstâncias, mas garanto a você: não encontrarão o culpado. O condutor me contou que Kháilov sofreu muitos ferimentos - foram sete, no total. Surpreendentemente, de algum jeito os condutores sempre sabem tudo. Dois ferimentos mortais - no peito e na garganta. Os demais foram na barriga, mas com sua camada de gordura visceral, era como grão de chumbo em elefante. E daí? E daí que, de qualquer maneira, o assassino não estava sozinho, visto que dois golpes foram dados por um profissional, e cinco por um diletante. Alguém desceu do trem entre Baranóvka, onde Kháilov nos visitou ainda vivo, e

9 Poeta bengali (1861-1941), um dos principais representantes da cultura hindu, laureado com o Nobel de Literatura em 1913. Foi bastante traduzido na Rússia durante o século XX, sobretudo por poetas simbolistas e, mais tarde, por Boris Pasternak e Anna Akhmátova. Visitou a URSS deixando um livro de cartas sobre suas impressões. 
Krasnokámensk, onde o acharam morto? Desse, ninguém foi atrás, era de noite, os condutores são preguiçosos. Agora procuram essas pessoas como agulha no palheiro, assim como a arma do crime. Enquanto isso, temos a chave na mão, e se o senhor lesse com atenção o meu Código de Afrodite...

- Eu o traduzi! - explodiu Syromiátnikov.

- Traduzir não significa ler. Seu coração está fechado, o senhor não limpou seus chacras com o meu livro. Mas ele está lá para isso! Teria prestado atenção na grande importância dos números em nossa vida. E teria notado que, no começo da atividade profissional, Kháilov teve exatamente sete cargos, e em cada um deles - eu notei isso especialmente! - esmagou e oprimiu todos os vivos sem cansar. Sim, e os cargos eram apropriados - em outros não o colocariam. Ele começou na categoria de oficial e foi promovido a major, mas depois o expulsaram do exército - ainda no tempo soviético - por excesso de crueldade! Isto está escrito até no dossiê dele, que está na internet. Muitas vezes ele desmentiu essa informação, citou testemunhas, trocou beijos com antigos soldados, os quais teriam servido sob seu comando - mas no olhar dos soldados drapejava o horror, apesar de terem servido há muito tempo. Oh, eu olhei o dossiê dele em detalhes, eu de fato me interessei por esse rapaz, que descanse em paz no inferno... Depois do exército tornou-se comissário militar e regularmente cumpria o plano de prender recrutas evadidos - o senhor tem experiência nisso, eu sei. Acho que nesse cargo ele acumulou um número gigantesco de inimigos! Por seu êxito total, transferiram-no para a chefia do partido - e já ali ele se virou, sem cansar, erradicando a subversão. Na década de 90 não era bem-visto se orgulhar disso, mas no ano passado ele contou a jornalistas que conduziu pessoalmente a julgamento cinco subordinados - isso foi antes de sua secretária-geral kagebista, que... bom, esse, de óculos...

- Andrópov ${ }^{10}$ - disse Syromiátnikov, azedo.

- Oh, sim, antropos... $\mathrm{Na}$ época dele prenderam muitos, mas por algum motivo isso é lembrado como um primeiro sopro de liberdade. Não admira que com o começo da liberdade nosso falecido amigo - essa foi a quarta etapa de sua carreira - fundou uma cooperativa e ficou famoso por massacrar os concorrentes. Um de seus companheiros foi encontrado com o crânio aberto, e ele tinha três filhos, todos meninos... Você está seguindo meu raciocínio?

- Estou - acenou Syromiátnikov. - Faltam três cargos.

10 Referência a Iúri Vladímirovitch Andrópov (1914-1984), secretário geral do Partido Comunista posterior a Leonid Brejnev, e chefe da KGB, o serviço secreto soviético, durante quinze anos. 
- A seguir tudo é simples. - Coqtelho encolheu os ombros. - Na categoria de deputado ele se recusou a ajudar dez crianças doentes, cada uma de um pai. Na categoria de chefe adjunto da administração municipal, fechou o jornal que o criticava, e o jornalista, que nisso havia especialmente se empenhado, foi encontrado com a cabeça partida - pelo visto, essa era sua marca registrada. Finalmente, no ano passado ele conseguiu prender seu suplente, que sabia algo sobre ele, e esse suplente com certeza tem parentes... Em todos esses feitos ele se comportou como um touro furioso pressionado, a essas pessoas nós chamamos assim, chifrudos. Todos o temiam, mas em determinado momento o medo se transforma em fúria - assim é a psicologia popular. E se o investigador tem a cabeça no lugar, ele facilmente calculará a interseção dos conjuntos necessários. Basta verificar por computador se em nosso trem viajou algum dos jovem recrutados por ele que deixaram em casa pais doentes e indefesos. Se esteve no vagão algum dos padrinhos de seus cinco funcionários. Se saiu em Tchitá algum parente do substituto assassinado. E et coetera - tudo isso, como o senhor entende, se faz em uma semana na presença de mensageiros rápidos e com acesso regular à internet. Quero notar que assassinato coletivo por vingança social é um motivo extremamente tentador, e não é de se excluir que eu pondere sobre um livro com esse tema já em nossa viagem. Para escrevê-lo não vai levar muito tempo. O senhor há de concordar que o esquema tradicional do romance policial aqui se rompe em essência - geralmente escolhemos um entre muitos, mas aqui nos é oferecida uma variante, na qual todos são assassinos.

- Ouça, Vladímir - disse Syromiátnikov, sorrindo contra vontade. Não podia resistir ao encanto daquele vigarista. - Você realmente acredita que ninguém leu Assassinato no expresso do Oriente?

- Acredito que poucos leram - observou Coqtelho com calma. - Além disso, o senhor está se esquecendo da cor local. Do enorme panorama da Rússia, do ómul, do taimen, da maravilhosa culinária - o leitor ama menções às comidas deliciosas, isso lhe é não menos importante que a descrição de um bom sexo... E claro, do principal - o alto senso moral. Imagine: a Rússia de joelhos se põe de pé. O país, humilhado por muitos anos, extenuado pela pobreza, deixando de distinguir o bem do mal - por fim se vinga de anos de sofrimento, punindo um daqueles que o trataram cruelmente durante todo esse tempo. O ex-funcionário do partido, que ganhou favores dos novos donos, definha nas mãos da nova Rússia - e quem investigará esse crime?! Um estrangeiro com propensões humanistas, um homem do Ocidente, que conhece perfeitamente a mentalidade do Oriente e está pronto para, caso necessário, fornecer um álibi para todos assassinos, e pôr a culpa... bom, pelo menos em seu tradutor - um cara entediante e rabugento, eternamente insatisfeito com a própria carreira literária! 
Coqtelho deu um tapa no ombro de Syromiátnikov e uma gargalhada ensurdecedora.

Syromiátnikov, por sua vez, não gostou da piada. Olhou Coqtelho com olhinhos pequenos e pálidos, que tinham visto muitos malfeitos provincianos, e balançou a cabeça.

- Você é um escritor fraco, Volódia.

- Por que isso, meu jovem amigo?!

- Porque olha para o país pela janela do expresso do Oriente. Mas a Rússia não é para você Baikal de olhos azuis. Não há nenhuma nova Rússia, Volódia, nem nunca haverá. E de joelhos ninguém vai se pôr de pé. E se vingar da morte, da prisão, da humilhação, da pobreza e vergonha aqui também ninguém vai, entende? Já houve uma experiência como essa, suficiente para toda a vida. "Uma nação de escravos, de alto a baixo - são todos escravos!" "11 O senhor sabe quem disse isso? Um homem que viu na vida mais merda que você. E eu, a propósito, sei quem viajava com Kháilov na cabine. É uma autoridade criminosa famosa em Primórie, Bala, aquele mesmo que lhe pediu autógrafo anteontem. Ainda disse que leu você no cárcere e que você transformou a alma dele.

- Eu lembro - respondeu Coqtelho, curioso. - E o que houve?

- Houve que Bala não suporta quando roncam perto dele! - exclamou Syromiátnikov triunfante. - E eu sei disso perfeitamente porque também leio a imprensa local. E desde que matar uma pessoa para ele é como enviar dois faxes, então, no escuro, ele atingiu Kháilov sete vezes onde quer que fosse! Ele então parou de roncar, e era disso que Bala precisava. Deitou-se tranquilamente de novo e pegou no sono, porque toda a milícia local estava mancomunada. Aliás, sobre isso até Moscou sabe, mas fazer Bala falar, isso não conseguem de jeito nenhum. Ele está intimamente ligado com alguns piterenses. Chega de blá-blá-blá, Volódia. Você nunca escreverá nada sobre a Rússia porque não a entende. Mas se escrever, esse seu livro vai fracassar por aqui. Aqui nunca se rebelam e nunca se vingam de ninguém, aqui vão engolir mais dez mil Kháilovs e esquecer tranquilamente toda sua arte. E aqui matam pelo ronco, entende?

Coqtelho se calou.

-É por isso que eu sou um autor best-seller e milionário, e você meu tradutor com uma dúzia de romances não publicados - disse com ares de importância.

11 Citação de excerto do romance Prólogo, de Nikolai Gravílovitch Tchernichévski, feita por Lênin em seu discurso "Sobre o orgulho nacional dos Grão-Russos", proferido em 1914. 
- Por quê? - Syromiátnikov não entendeu.

- Porque eu ofereço uma versão que lisonjeia o leitor. Enquanto você aponta no nariz dele uma mentira humilhante, que ninguém precisa para merda nenhuma. Quem precisa desse seu Cartucho e desse seu assassinato por ronco? E compara isso com o meu tema maravilhoso, do qual provêm ricos sentidos metafísicos! Compara isso com a bela e fascinante história que sugeri - com base em Agatha Christie, porque mastigado é mais fácil de digerir... Enquanto a sua versão - suja, risível, e para dizer a verdade, idiota - não está mais perto da verdade do que a minha!

- É? - perguntou Syromiátnikov ofendido.

- É! - gritou Coqtelho. - Na verdade, tudo não se deu de forma tão complicada, como a minha, nem tão simples quanto a sua. Você com certeza lembra como eu, às seis da manhã, passei por você no corredor? Eu praguejei de propósito na sua porta!

- Você quer dizer que... que... - Syromiátnikov ficou sem ar.

- "Mude a vida, em que puder, e não duvide do seu direito" - disse Coqtelho, cortando mais um pedaço de ómul. - Agenda do Guerreiro de Prata, parte dois, capítulo quinze.

\section{Убийство в Восточном экспрессе (Амитрий Аьвоович Быков)}

Сначала подали заливное из мося, потом розового, тающего во рту копченого тайменя, Аиловый и пряный паштет из Аичи, сыр «Охотничий» с зеленью, потом красно-бурую, волокнистую вяленую медвежатину, блюдо очищенных кедровых орехов, ко всему этому «Таежную» на калгане, потом крепкий бульон с круглыми, толстыми, ручной Аепки пельменями опять-таки из Аосятины,- потом жареный кабаний бок с капустой, соленой черемшой и моченой брусникой, и Володя Коктельо-Перверте все это жрал. Он жрац, мощно Авигая челюстями, одобрительно кивая подавальщицам, подмигивая переводчику, жрал, словно его не кормили во Франции, Германии и Польше, которые он посетил перед российским турне, словно нажирался за всю свою голодную юность, потраченную на постижение верховной мудрости в мансардах Парижа и трущобах Буэнос-Айреса. Европейский писатель изысканно колупнул бы там, понюхал тут и отломил хлебца - и достаточно, но Коктельо-Перверте был матиноамериканец и хорошо знац, что, пока кормят, надо жрать. Потом не будут. Только эта большая школа бурно прожитой жизни и примиряла Сыромятникова с 
Перверте, хотя бы отчасти. Чувствовался человек не только понюхавший, но и хлебнувший.

Прославленный сочинитель эзотерических Аетективов, покоритель межАународного книжного рынка, Аичный Аруг Мадонны, Аюбимый партнер Пола Маккартни по бриджу, крокету и трансцендентальной медитации, Ауховник Марадоны, талисман сборной Аргентины по хоккею на траве, регулярный гость Сорбонны, крестный отец внебрачного сына Челентано и крестный сын Аалай-цамы, принявший в будАизме имя Суттипон Бхатхабратха, что значит, Аолжно быть, настырный мысый проныра с закосами под Ауховного вожАя,- Володя Коктельо-Перверте родился в семье крупного Аатифундиста, сиречь землевладельца, в 1951 году. Его отец увлекался илеями Аенина и назвал сына в его честь, но, к счастью Аля Володи, ограничивался теорией, исповедуя на практике хищнический капитализм самого мафиозного образца. Сынок, Ауховный учитель европейского студенчества, кумир американских кампусов и кубинских компаньерос, унаследовац от папы счастливую способность исповедовать одно и практиковать Аругое. Отправившись учиться в Париж, он перепробовал там все виды нейростимуляторов и психоделиков, забросил учебу, клошарил под мостами, странствовац по Европе, зарабатывац на жизнь всем - от киАнепинга Ао куннилинга - и был обнаружен встревоженным папашей в амстердамской коммуне маоистов-растаманов, поклонявшихся беременной негритянке, Матери Миров. Папа справедливо заключил, что образование сына закончено, и поместил его на отдых в психиатрическую Аечебницу под Буэнос-Айресом, где Володю впервые пронизал так называемый Розовый Свет. Под Аействием этих теплых волн он записал как бы продиктованный ему свыше первый эзотерический детектив «Смерть бедуина», герой которого, сыщик и мистик Рабан, путешествуя по эпохам и континентам, в конце концов ущучивац мировое зАо. Перверте было совершенно нечего Аелать в комфортабельном заключении, таблетками его пичкали исправно (Аа, говорят, он вдобавок обольстиц красивую медсестру, снабжавшую его также гашишем) - знай читай Аа галАюцинируй. Он прочел «Тысячу и одну ночь», Борхеса, суффиев, пару популярных толкований Нового Завета - и основал жанр, принесший ему громкую славу. Все Авадцать три сляпанных им мистических детектива о странствиях Рабана по Борхесу и суфиям, с регулярными заходами в Ватикан, Мекку, Иерусалим, эпоху крестоносцев и расцвет Венеции, одинаково напоминали рахат-лукум, завернутый в страницу из потрепанной Британской энциклопедии. ОАнажды Сыромятников купил такой рахат-лукум в Стамбуле и поразился буквальности сходства: вязко, 
слаАко, и ко всей этой Аипкой экзотике прилипли фрагменты исторического справочника. Однако высоколобые называци Перверте главным матиноамериканским постмодернистом, а массовый читате ь скупац «Смерть муфтия», «Украденный Коран» и «Каббалу святош» в таких количествах, что через пять мет митературной карьеры Володя приобрел психиатрическую мечебницу, гле его озарило, и основац там Межконфессионацьную школу Ауховного просвещения. Там изучали его духовный завет народам всего мира - «Настольную книгу Светоносца». Бухгалтерию вела та самая вечно беременная негритянка, которой он поклонялся в Амстердаме.

Сыромятникову досталось все это переводить - в университете он выучиц испанский. Сам он тоже писац детективы, и гораздо мучше, чем Коктельо, но они никому не были нужны, поскольку сыромятниковских героев убивали не в Аувре, а в провинциальных гостиницах, и убийцами были не монахи тайного ордена Вольтерьянцев, а доведенные до отчаяния местные безработные. Из его детективов нельзя было сляпать даже сериал. В результате он кормился с Коктельо и перепер на язык родных осин уже шесть его неотличимых поделок, вкАючая только вышедший «Шифр Афродиты». Российская мода на Владимира начацась с Макаревича, который познакомился со смуглым толстяком во время Аайвинга в южных морях и пригласил в Россию. Он же привез сюда экземпляр «Ежедневника Серебряного Воина» и во время презентации очередного Аиска показал главному редактору «Эксни». «Эксня» быстро смекнула, чем пахнет,- ей предлагалась вся мировая культура и религия в одном флаконе, пережеванная, отрыгнутая и поперченная,- и скоро широкий хавацьник светоносного

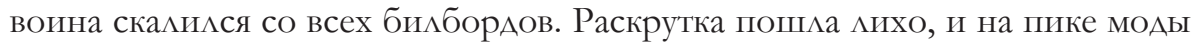
Коктельо был приглашен на снежный Восток мирового Ауха, как обозвал он Россию в первом же московском интервью. Слоганом поездки стало название нового романа «На Восток!»: Перверте выразил желание проехать по России - от Москвы до Читы,- встречаясь с поклонниками в крупных городах и издали благословляя мелкие. К Восточному экспрессу «БайкаАьская синь» прицепили салон-вагон, в нем оборудоваАи роскошное купе Аһя Перверте, купе Аля мужеподобной секретарши-сербки, еще одно - Аһя женоподобного секретаря-колумбийца (Сыромятников все не мог понять, с кем из них сожительствует воин света), самому переводчику выделили скромную клетушку близ сортира, и под щелканье блицев Аруг Мадонны отчалиц в свое первое русское паломничество.

Он был, в общем, неплохой мужик, отлично знавший цену своей продукции. Облачаясь в расшитый серебряный халат и белоснежную 
чалму перед остановками в Казани и Новосибирске, Коктельо насвистываА себе под нос что-то революционное, причем с таким хитрованским видом, что Сыромятников однажды не удержался и подмигнул ему. Переводить его тарабарщину было удивительно мегко - он нес полную пургу и предостав яя переводчику украшать ее как угодно. «Я не обижусь, amigo,- пророкотал он при первой же встрече,- если в синхронном переводе вы сколь угодно Аалеко отойдете от оригинала. Положитесь на вашу фантазию, индуцированную присутствием моего могучего духа! Ха! Ха!» - и Сыромятников ни в чем себе не отказывал. «Регулярный пост по четным числам, воздержание от супружеских обязанностей по нечетным, созерцание созвездия ЗаАумчивой Крысы, как называют у нас в Бразилии Большую Медведицу, и прочистка чакр гигиеническим ершиком фирмы «СаАем», совладельцем которой я яв^яюсь, поможет вам уже к концу первого года занятий достигнуть Степени Поглощения, от чего только оАин шаг и полгода тренировок до Стадии Испражнения!» - бесстыдно чесал он, почти не прислушиваясь к болботанию ВАадимира. Вечерами они прекрасно выпивали в салоне мэтра, благо на его Аюбимый «Ажек Аэниелс» издатель не скупился.

- Мой Аар предвидения подсказывает мне, молодой Аруг,- хитро щурясь, говорил Перверте,- что вы и сами пописываете, о Аа, и весьма успешно. Признайтесь, я угаАац?

- Не без того.

- И печатают?

- Плохо.

- Ничего, все с чего-то начинали... Мне кажется, вся ваша проблема в том, companiero, что вы не знаете жизни. Еще Филель, когда мы охотились в его угодьях, однажды сказал мне: жизнь, надо знать жизнь! Че читал книжки,

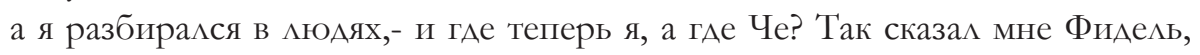
а Фидель хитрый парень. Я постранствовац, о Аа, я повидал всякого,- и он загибал очередную историю, которой позавидовац бы Максим Горький. Перверте проехал всю Европу, месяц прожиц среди африканских пигмеев, снимал документальный фильм о королевских пингвинах, занимался благотворительностью среди аборигенов Океании, везде дегустировац национальную кухню и оставля потомство. «Я щеАро размазал себя по этому грязному глобусу, так-то, amigo! Жить надо со вкусом, как сказал мне Уго Чавес, отобрав у очередного олигарха всю его собственность. Вот вам тридцать пять, а что вы можете вспомнить?» 
Сыромятникову, конечно, было что вспомнить - грязные дороги российской провинции, сотни изломанных судеб и тысячи кислых мин, на которые он насмотрелся в качестве редактора отдела расследований «Трибуны», серые папки одинаковых уголовных дел - копеечные грабежи и многолетние сроки, бессмысленные побеги и опять сроки, кража проводов и трансформаторов, развинчивание рельсов, побеги из армии,- но из этого нельзя было изготовить даже один бестсемлер типа «Завещания Мавра». Почему-то читатель упорно отказывался читать про то, что его окружацо, плевать хотел на страдания парализованного соседа и нищей соседки, но проливац реки слез по Изауре, которая жила на Аругом конце земли, Аа и то искАючительно в больном воображении продюсера.

Коктельо изучал русскую жизнь широко и основательно. На встречах в книжных магазинах он не столько говориц, сколько слушал; Сыромятников переводиц ему криминальную хронику из местной прессы; проводниц и подавальщиц он не только исщипал до синяков, к полному их блаженству, но и расспросиц о мацейших биографических подробностях, вплоть Ао начала месячных и привычек свекрови; жаАность его к еле, выпивке и впечатлениям была поразительна. С пяти утра он что-то выстукивал на крошечной «Тошибе» с мичной монограммой, потом наговаривац на Аиктофон колонки Аля Авух аргентинских газет (расшифровка межала на секретаре), потом вносиц правку в только что оконченную автобиографию А^я «Penguin books» (в этом помогала секретарша), потом так же неутомимо обедал и темпераментно давал пресс-конференцию в очередном сибирском городе. Сыромятников Аивился его неуемности и российской необъятности: Перверте производил страшное количество одинаковой продукции, за окном тянулось страшное количество одинаковой России - по сравнению с компактным Западом ее Восток поражац избыточностью и запущенностью,и в этом смысле гость и хозяйка были Аруг Аля Аруга созданы. На кажАой станции поклонники дарими Перверте сувенир, он раздавац тысячи автографов, не уставая спрашивать имена читателей и на каждой пятой книге рисовать голубка, а вечерами, когда за окном тянулась Аолгая, хвойная, сырая, без единого огонька тьма,- рассказывац Сыромятникову главы будущей автобиографии. Иногда Сыромятникова тошнило от Коктельо, но, в общем, он был признателен кормильцу.

В прочем экспрессе - не таком роскошном, но тоже элитном - ехаци местные в^асти, чиновники, бизнесмены, не имевшие к митературе никакого отношения, но знавшие, конечно, что к поезду прицеплен салон живого классика. Некоторые, по особому разрешению, заходили познакомиться. В 
салоне Коктельо побывали вице-губернатор Челябинска, крупный финансист из Екатеринбурга, глава фирмы «Safe Siberia», производящей контрацептивы, и прославленный бывший народный депутат от фракции «Неразрывность», ныне преуспевающий Аальневосточный банкир Борис Хайлов - тучный медведь, на фоне которого Перверте выглядел почти изящным. Хайлов Аолго цитирова^ «Ежедневник Серебряного Воина», рассказываА о своем Ауховном пути и о том, как много он жертвует на храмы, а также о том, как стремительно улучшается Россия в условиях централизации. Книги Коктельо у Хайлова не оказалось, и он преАложил ему расписаться на плоском животе Аевушки из модельного агентства «Сибирские огни». Коктельо попросил секретаршу отвернуться и расписался у девушки на заднице, взяв с нее обещание не мыть задницу по крайней мере неделю.

- Интересный человек,- сказал он вечером за стаканом «Ажека».- Учитесь, amigo, пока он жив. Что-то подсказывает мне, что осталось ему неАолго.

- Такие не умирают,- буркнул Сыромятников.

- Своей смертью - практически никогАа,- кивнул Коктельо.- УАивительный тип. Чистая, беспримесная тьма, без единого проблеска. Я думаю, Господь хотел бы вставить в него Аушу, но не может найти в этом монолите ни единого возАушного пузырька. Феномен, феномен. Я приберегу его ААя романа.

- У нас тут таких - каждый второй,- наябедничал Сыромятников на родину.

- Ошибаетесь. Перед встречей я изучил его биографию - поручил Розе подготовить Аля меня сводку...- Розой звали сербку, похожую скорее на Аиванский кеАр.- УАивительно, где он только не наследил. У вас это ведь часто - что один и тот же управленец рулит во многих сферах? У нас, в Аргентине, в Бразилии,- так не принято. Мы в западный менеджмент не верим. Начальником может быть только тот, кто прошел все ступени и досконально изучил бизнес. А этот кем только не был - военкомом, снабженцем, главным редактором... Нет, это очень интересный тип. Я не хотел бы им быть за все ароматы Аравии. Кстати, рассказывац я вам, как один саудовский шейх подариц мне наложницу, арабку-альбиноску?..

Он рассказывац Аолго, смачно, с удивительными подробностями,и отпустил Сыромятникова только в третьем часу ночи, Аа и то Аишь потому, что сослался на Аегкий понос. «Все-таки, знаете, тяжелая кухня...» Сыромятников слышал утром, сквозь сон, как Перверте грузно топочет по коридору в сортир и, после Аолгого пребывания в нем, обратно - ругаясь 
столь художественно, что перевести этот изысканный испанский мат он бы затруднился.

Утром, на подъезде к Чите, в маленьком Краснокаменске, где у Перверте не планировацось ни встреч, ни автограф-сессий,- поезА остановицся надолго. На перрон никого не выпускали. Станция была запружена мимицией. По ней беспомощно метались бюрократического вила персонажи в распахнутых пальто, с растерянными и зАыми мордами. Наконец из седьмого вагона вынесли на носилках что-то огромное, покрытое бемой простыней.

- Я схожу, разведаю?- вызвался Сыромятников.

- Что вам неясно?- барственно спросиц Коктельо.- Это наш друг, представитель партии «САипшиеся», хозяин «Трах-бах-банка», или я не предупрежлал вас?

- Вы и будущее угадываете?- кисло спросил Сыромятников. Самодовольство этого Аюбимца Рабиндраната Тагора начало утомлять его.

- А как же. Я еще пять мет назал говориц Полу: Поц, ты бросишь Хизер, эта Аевочка не Аля тебя. Сначала он смеялся, потом обозлился. А месяц назал прислац мне торт. Если бы он знац меня в восьмидесятом, может, я предупредим бы и Ажона...

- Что ж вы этого не спасли?

- Аа ведь он знац,- сказал Коктельо.- Он только не знац когда.

ПоезА тронулся только около полудня. Коктельо жевац омуля, мечтательно запивая его «Сибирской порфирой».

- Вот вы детективщик, или по крайней мере так себя позиционируете,- буркнул Сыромятников.- Уверен, однако, что Аоведись вам раскрывать настоящее убийство - вы немеАленно спасовали бы.

- Вообще-то, юноша,- назидательно ответил Коктельо, не отводя глаз от тайги за окнами,- повара не охотятся за дичью, а метациурги не ищут руду. Я обрабатываю жизнь, а не переделываю ее.

Эта восточная высокопарность была в нем особенно противна Сыромятников никогда не понимац, как могут Аюди со средним образованием покупаться на такую дешевую бутафорию.

- Но поскольку я потерся среди Аюдей и много всего повидац в бурной юности,- продолжал Перверте, закуривая толстый «Упман»,- я мегко расколол бы дело средней сложности, если бы мне не мешали. Сейчас в седьмом вагоне илет дознание, целая бригада местной полиции запущена в 
поезА Аля выяснения обстоятельств, но уверяю вас - виновного не найАут. Проводник мне поведац, что Хайлову нанесены множественные раны - общим числом семь. УАивительно, откуда проводники всегда все знают. Аве раны смертельны - в грудь и в горло. Остальные пришлись на живот, но с его жировой висцеральной прослойкой это - слону Аробина. СлеАовательно? Следовательно, убийца был по крайней мере не один, ибо два удара нанесены профессионалом, а пять - дилетантом. Соше $\Lambda и$ кто-нибудь с поезда между Барановкой, где нас посетил еще живой Хайлов, и Краснокаменском, где его нашли мертвым? За этим никто не проследил, дело было ночью, проводники менивы. Ищи-свищи теперь этих Аюдей, как и орудие убийства. А межАу прочим, у нас в руках кАюч, и если бы вы внимательно читали мой «Шифр Афродиты»...

- Я его переводиц!- взорвался Сыромятников.

- Переводить - не значит читать. Ваше сердце закрыто, вы не прочистили свои чакры моей книгой. А она стоит того! Вы обратили бы внимание на великую роль чисел в нашей жизни. И запомнили бы, что с начала трудовой деятельности Хайлов смениц ровно семь Аолжностей, на кажАой из которых - я специально заметил это!- без устали подав ял и угнетал все живое. Аа и Аолжности были соответствующие - на Аругие его не поставици бы. Он начинал в качестве офицера и дослужился до майора, но потом его выгнали из войск - еще в советское время - за особую жестокость! Это написано даже в его досье, которое есть в Интернете. Он многократно опровергал эту информацию, приводиц свидетелей, целовался с бывшими солдатами, которые якобы служили под его начацом,- но в глазах солАат плескался ужас, хотя служба Аавно была позади. О, я подробно просмотрец его досье, меня в самом деле заинтересовац этот парень, аА ему пухом... После армии он слелался военкомом и регулярно выполня п план по аресту укАонявшихся призывников - у вас это практикуется, я знаю. Аумаю, на этой Аолжности он нажил страшное количество врагов! За отличные успехи его переводят в партийные начальники - и уж тут он развернулся, без устали искореняя крамолу! В девяностые у вас не принято было этим гордиться, но в прошлом году он поведал журналистам, что мично Аовел до суда пятерых подчиненных - это было при вашем гэбэшном генсеке, который... ну этот, в очках...

- Андропов,- кисло сказал Сыромятников.

- O да, antropos... При нем сажали очень много, но почему-то это запомнилось как первое веяние свободы. Немудрено, что с началом свободы 
наш покойный Аруг - это быц четвертый этап его карьеры - создал кооператив и прославился расправами с конкурентами. ОАин его компаньон был найден с раскроенным черепом, а у него ведь было трое детей, все мальчики... вы следите за моей мыслью?

- Слежу,- кивнул Сыромятников.- Остались три должности.

- А дальше все просто,- развел руками Коктельо.- В качестве депутата он отказал в помощи десятку больных детей, у каждого из которых был отец. В качестве заместите я главы городской администрации закрыл газету, критиковавшую его, а журналиста, который в этом особенно усердствовац, нашли с пробитой головой - виАимо, это его фирменный стиль. Наконец, в прошлом году он добился ареста своего заместителя, который кое-что про него знац,- а у этого заместителя тоже наверняка есть родственники... Во всех этих делах

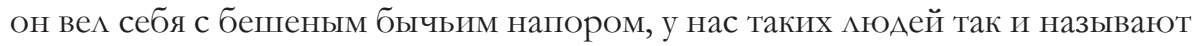
- рогачами. Его боялись все, но в какой-то момент страх переходит в гнев такова народная психология. И если у следователя есть на плечах кой-какая головенка, он Аегко вычислит пересечения нужных множеств. Аостаточно узнать по компьютеру, ехац Аи в нашем поезде кто-нибудь из призванных им юношей, у которых дома остались больные беспомощные родители. Был Аи в вагоне кто-нибудь из посаженных им пятерых чиновников. Выезжали ми из Читы родственники убитого заместителя. И так далее - все это, как вы понимаете, дело одной недели, при наличии расторопных курьеров и регулярного доступа к Интернету. Хочу заметить, что колмективное убийство из социальной мести - весьма соблазнительный мотив, и не исключено, что книгу на этот сюжет я обдумаю уже в нашей поездке. Ее написание не займет много времени. Согласитесь, что схема традиционного Аетектива зАесь существенно момается - обычно мы выбираем одного из многих, но тут нам предлагается вариант, при котором убили все!

- Слушайте, В^аАимир,- сказал Сыромятников, против воли улыбаясь. Он не мог противиться обаянию этого жулика.- Вы действительно полагаете, что никто не читац «Убийство в Восточном экспрессе»?

- Полагаю, что читали немногие,- невозмутимо заметил Коктельо.Кроме того, вы забываете о местном колорите. О широкой панораме России,

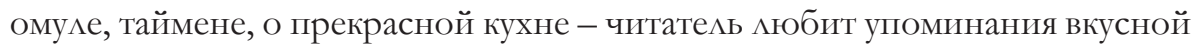
еды, это Аля него не менее важно, чем описание хорошего секса... И конечно, главное - высокий нравственный смыс . Вообразите: Россия поднимается с колен. Страна, многие годы униженная, измученная нищетой, переставшая различать добро и зАо,- наконец мстит за многолетние страдания, наказывая 
одного из тех, кто так жестоко с нею обходился все это время! Бывший партийный чиновник, выслужившийся при новых хозяевах, гибнет от рук новой России - и кто же расследует это преступление?! Гуманно настроенный иностранец, человек с ЗапаАа, отлично знающий ментальность Востока и готовый в случае необходимости предоставить алиби всем убийцам, а вину свалить... ну, хотя бы на своего переводчика - скучного и брюзгливого

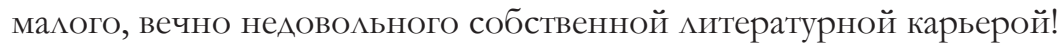

Коктельо хиопнул Сыромятникова по плечу и оглушительно расхохотался.

Сыромятников, однако, не принял шутки. Он посмотрец на Коктельо маленькими блеклыми глазками, видевшими так много провинциальных зАодейств, и покачац головой.

- Плохой вы писатель, Володя.

- Почему это, мой юный Аруг?!

- Потому что смотрите на страну через окно Восточного экспресса. А Россия - это вам не «Синеглазый Байкам». Никакой новой России нет, Володя, и никогда не будет. И с колен никто не встает. И мстить за гибель, тюрьму, унижения, нищету и позор здесь тоже никто не будет, понимаете? Был уже один такой опыт, на всю жизнь хватило. Нация рабов, сверху донизу - все рабы! Знаете, кто это сказац? ОАин человек, который повиАац в жизни

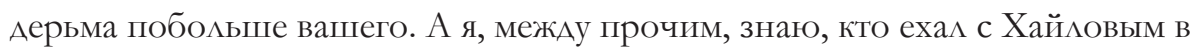
купе. Это известный в Приморье криминальный авторитет Пуля, тот самый, который просиц у вас автограф позавчера. Еще сказал, что прочел вас в заключении и вы перевернули его душу.

- Помню,- заинтересованно откликнулся Коктельо.- И что же?

- А то, что Пуля не выносит, когда при нем храпят!- торжествующе воскАикнул Сыромятников.- И я отлично это знаю, потому что тоже читаю местную прессу. А поскольку убить человека Аля него - как два факса отослать, то он и нанес Хай ову в темноте семь ранений куда попало! Тот перестал храпеть, а Пуле этого и нало. Он спокойно мег обратно на полку и заснул, потому что вся местная милиция у него в кармане. МежАу прочим, об этом и в Москве знают, но сковырнуть Пулю не могут никак - он тесно связан с некоторыми питерскими. Не надо Ая- я, Володя. Вы никогда ничего не напишете о России, потому что не понимаете ее. А если напишете, эта ваша книга здесь провалится. 3Аесь сроду не бунтуют и никому не мстят, зАесь проглотят еще Аесять тысяч Хайловых и спокойно забудут все их художества. А убивают здесь из-за храпа, понимаете? 
Коктельо помолчал.

- Вот поэтому-то я автор бестселмеров и мимлионер, а вы мой переводчик с Аюжиной ненапечатанных романов,- сказал он важно.

- Почему?- не понял Сыромятников.

- Потому что я предлагаю версию, которая мьстит читателю. А вы тычете ему в нос унизительной Аожью, которая на фиг никому не нужна. Кому нужны этот ваш Патрон и это ваше убийство из-за храпа? И сравните это с моим прекрасным сюжетом, из которого выводятся богатейшие метафизические смыслы! Сравните это с красивой и увлекательной историей, которую предложиц я - пусть на основе Агаты Кристи, потому что уже съеденное Аегче усваивается... А ведь ваша версия - грязная, смешная и, по правде сказать, идиотская,- ничуть не ближе к правде, чем моя!

- Аа?- спросиц уязвленный Сыромятников.

- Аа!- грохнул Коктельо.- На самом деле все обстояло вовсе не так сложно, как у меня, и не так просто, как у вас. Вы же помните, как я в шесть утра прошел мимо вас по коридору? Я специально чертыхался у вашей Авери!

- Вы хотите сказать... сказать...- задохнулся Сыромятников.

- «Измени жизнь, где можешь, и не сомневайся в своем праве»,- сказал Коктельо, отрезая еще кусок омуля.- «Ежедневник Серебряного воина», часть вторая, глава пятнадцатая.

\section{Referências}

BÝKOV, Dmítri. JD-Rasskasy. Moscou: Vagrius, 2007. 